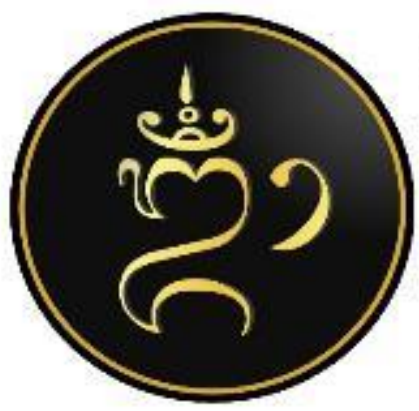

E-ISSN: $2722-8576$

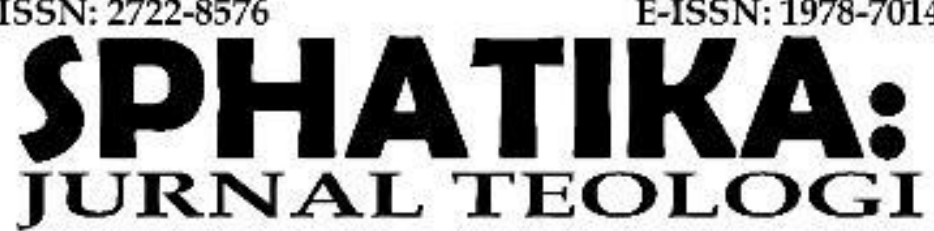

UNIVERSITAS HINDU NEGERI

I GUSTI BAGUS SUGRIWA DENPASAR

VOLUNE 12 NOMOR 1, MARET 2021

\title{
DHARMA SEORANG RAJA DALAM MEDAN PERANG KURUKSSHETRA (KAJIAN TEOLOGI TERHADAP PERCAKAPAN YUDHISTTHIRA DAN BHISMA)
}

\author{
Putu Dana Yasa ${ }^{1}$ \\ 1World Hindu Parisad \\ 1putu.dyasa@gmail.com
}

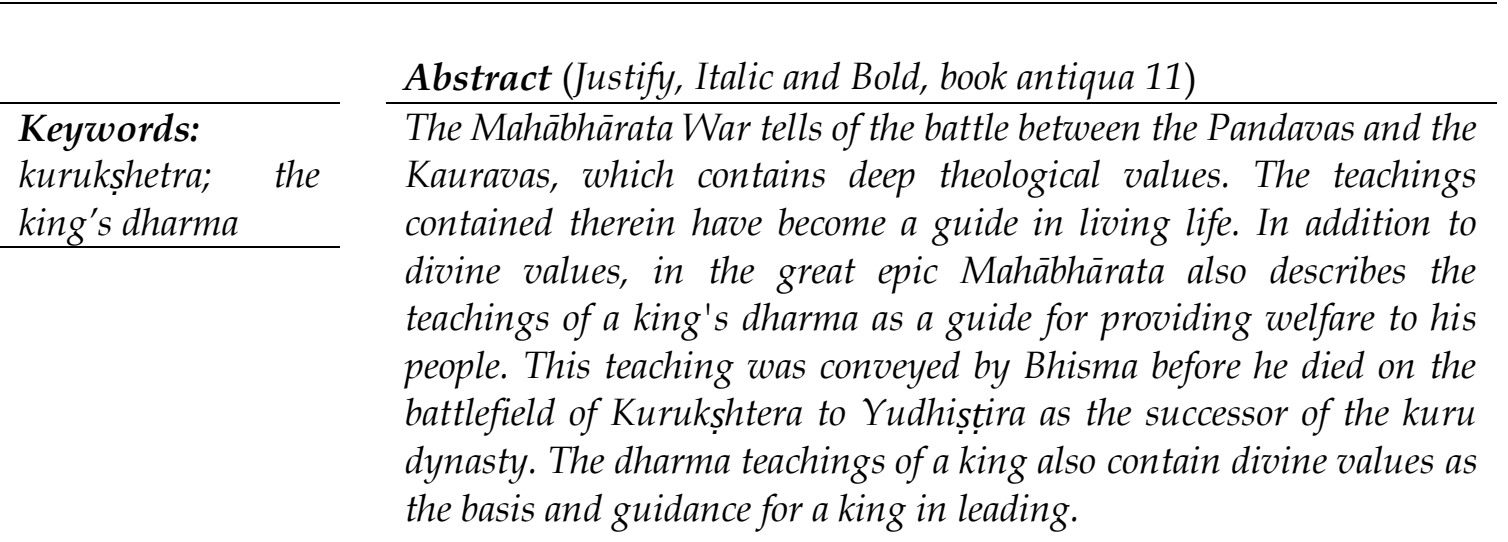

\section{Kata kunci: \\ Dharma seorang \\ raja, Kurukșhetra}

\begin{abstract}
Abstrak (rata kanan kiri, cetak miring dan tebal, book antiqua 11) Perang Mahäbhärata mengisahkan pertempuran pihak Pandawa dan Korawa mengandung nilai-nilai teologi yang mendalam. Ajaran yang tertuang didalamnya hingga saat ini menjadi tuntunan dalam menjalankan kehidupan. Selain nilai-nilai ketuhanan, dalam epos besar Mahābhārata juga menjelaskan ajaran tentang dharma seorang raja sebagai pegangan untuk memberikan kesejahteraan pada rakyatnya. Ajaran ini disampaikan oleh Bhisma sebelum gugur di medan perang Kurukștera kepada Yudhisțira sebagai penerus dinasti kuru. Ajaran dharma seorang raja ini juga mengandung nilai-nilai ketuhanan sebagai dasar dan juga pedoman bagi seorang raja dalam memimpin.
\end{abstract}

\section{PENDAHULUAN}

Kisah Mahābhārata merupakan salah-satu epos besar umat Hindu yang tertuang dalam kitab Itihasa atau yang dalam bahasa Indonesia disamakan dengan wiracarita hingga saat ini nilai-nilai filsafat maupun teologi didalamnya digunakan sebagai 
pegangan dan tuntunan dalam menjalankan kehidupan. Kisah yang tertuang dalam delapan belas parwa ini digunakan sebagai salah-satu sumber ajaran dharma karena didalamnya terkandung ajaran-ajaran kebajikan. Dalam keyakinan Hindu memahami Itihasa menjadi dasar utama sebelum mempelajari pustaka suci Veda yang memiliki tingkat kerumitan yang cukup tinggi dan terkadang akan susah dipahami apabila tidak memiliki dasar yang kuat serta guru yang benar-benar berkompeten.

Māhabhārata pada dasarnya menceritakan tentang kehidupan dari keluarga atau dinasti Kuru. Bagian yang tidak terlepas dalam epos Māhabhārata adalah perang saudara antara Pandawa dan Korawa dalam upaya menegakan keadilan pada kerajaan Hastinapura. Salah-satu penyebab munculnya perang ini adalah perlakuan memalukan yang dilakukan oleh Duryodhana dan pihak Korawa terhadap Drupadi. Dalam peristiwa tersebut, pakaian Drupadi berusaja ditarik oleh Dursasana karena sudah menjadi harta Duryodhana sejak Yudhișțira kalah dalam permainan dadu. Hal ini dilakukan tidak lain adalah dalam upaya merebut kekuasaan Hastinapura dari tangan Pandawa. Karena keinginan yang berlebihan dan tergiur akah tahta, Duryodhana menjadi tidak memikirkan kebenaran dalam setiap tindakannya.

Perlakuan memalukan yang diperoleh Drupadi menyulut kemarahan Pandawa terutama Bima yang saat itu bersumpah akan membunuh Dursasana dan meminum darahnya kelak. Setelah mengucapkan sumpah tersebut, Dhṛtarāṣtra merasa bahwa malapetaka akan menimpa keturunannya, maka ia mengembalikan segala harta Yudhișțira yang dijadikan taruhan. Duryodhana merasa kecewa akan keputusan ayahnya, kemudian meminta agar Pandawa kembali bermain dadu dengan taruhan menyerahkan kerajaan dan mengasingkan diri ke hutan selama dua belas tahun, kemudian hidup dalam masa penyamaran selama setahun dan setelah itu berhak kembali ke kerajaannya. Yudhișțira menerima taruhan tersebut, namun yang terjadi Yudhișţhira kembali mendapatkan kekalahan dan karena kekalahan tersebut Pandawa terpaksa harus meninggalkan kerajaan. Setelah masa pengasingan, sesuai perjanjian pada saat permainan dadu, pihak Pandawa berhak untuk mengambil alih kembali kerajaannya. Namun kembali Duryodhana bersikap jahat dan tidak mau menyerahkan kerajaan pada Pandawa, hal ini menyebabkan kesabaran Pandawa semakin habis. Berbagai upaya perdamaian dilakukan oleh Sri Kresna namun berkali-kali gagal dan peperangan tidak dapat dihindari (Suhardana, 2013: 760).

Akibat peperangan yang terjadi dalam medan perang Kurukșhetra tentu menimbulkan kesedihan akibat banyaknya kstrya yang gugur seperti Abimanyu, 
Drona, Bhisma, Karna, Gatotkaca, Raja Wirata dan masih banyak lagi kstrya yang gugur dalam perang yang berlangsung selama delapan belas hari tersebut. Kejadian inilah yang tertuang dalam beberapa Parwa dan digunakan sebagai dasar pengetahuan dharma bagi umat Hindu. Kisah Mahäbhārata diyakini memiliki nilai-nilai kehidupan yang berlaku sepanjang zaman, hal ini terbukti sejak terjadi perang Bhäratayudha yang dikatakan terjadi sekitar tahun 3186 SM yang juga merupakan akhir zaman Dwapara Yuga hingga saat ini keyakinan dan kepercayaan terhadap ajaran-ajaran kebajikan yang tertuang dalam epik Mahābhārata tetap menjadi pegangan dan tuntunan oleh masyarakat Hindu.

Dalam perang Bhäratayudha yang terjadi selama delapan belas hari ini juga memuat ajaran-ajaran yang tertuang dalam pustaka suci Bhagvadgĩtā yang juga disebut sebagai Pañcama Veda. Lebih spesifik, pustaka suci Bhagavadgìtā merupakan bagian dari Bhisma Parwa yaitu salah satu dari delapan belas parwa dalam Mahābhārata. Sehingga tidak salah apabila epos besar Mahābhārata hingga saat ini masih menjadi tuntunan masyarakat Hindu dalam upaya memahami secara utuh ajaran agama yang cakupannya sangat luas.

Berbagai ajaran dharma tertuang dalam kisah Mahäbhārata, salah-satunya adalah ajaran dharma seorang raja yang disampaikan oleh Bhisma kepada Yudhișțira saat telah dipenuhi anak panah disekujur tubuhnya. Ajaran ini disampaikan pada Yudhișțira yang diyakini memiliki kebijaksanaan tinggi sebagai penurus generasi Kuru. Kebijaksaan inilah yang menjadi pegangan seorang pemimpin atau raja dalam upaya memberikan kesejahteraan bagi rakyat yang dipimpinnya. Ajaran tentang dharma seorang raja disampaikan Bhisma tepat dalam penantian ajalnya di medan perang Kurukșhetra.

Ajaran dharma seorang raja disampaikan oleh Bhisma pada Yudhișțhira melalui sebuah percakapan di medan perang Kurukșhetra. Ajaran ini tertuang dalam kajian terjemahan parwa Mahäbhārata yang dilakukan oleh Kementerian Agama Republik Indonesia Ditjen Bimas Hindu tahun 2013. Hasil terjemahan dan kajian tersebut tersusun dalam sebuah buku dengan judul "Kisah Setelah Bharatayudha". Salah-satu yang menarik dalam tulisan tersebut adalah percakapan antara Bhisma dan Yudhișțira yang secara beruntun menanyakan perihal apa saja yang patut dilaksanakan oleh seroang pemimpin atau raja untuk dapat memberikan kesejahteraan pada rakyat.

Dalam percakapan Yudhișțira dan Bhisma memunculkan ajaran-ajaran kepemimpinan yang digunakan sebagai pedoman bagi seorang raja dalam menjalankan 
pemerintahan. Bhisma menjelaskan bagaimana seorang pemimpin menjadi tokoh utama dalam upaya memberikan kebahagiaan pada rakyat. Kebahagian rakyat adalah tujan utama bagi seorang pemimpin.

Pemimpin atau raja dalam keyakinan Hindu adalah orang yang terhormat, orang pilihan dan bahkan diyakini sebagai wakil Tuhan dalam upaya memanagement alam semesta. Ajaran kepemimpinan Hindu tertuang dalam berbagai pustaka suci, tentunya memuat ajaran teologi yang mendalam, salah-satu ajaran kepemimpinan Hindu tersebut terdapat dalam kisah Mahābhārata khususnya pada saat percakapan Yudhișțira dan Bhisma sebelum gugur di medan perang yang dapat digunakan sebagai dasar dan pegangan bagi seorang pemimpin dizaman Kali Yuga saat ini.

\section{METODE}

Kajian penelitian ini merupakan penelitian kualitatif yang menggunakan pendekatan teologi dalam hal ini erat kaitannya dengan konsep kepemimpinan Hindu yang mengandung nilai-nilai ketuhanan yang tidak terpisahkan dengan kewajiban dari seorang raja/ pemimpin dalam menjalankan kepemimpinan. Teknik pengumpulan data menggunakan teknik studi kepustakaan yang diperoleh melalui pustaka suci Hindu yang lebih khususnya pada bagian dari delapan belas parva epos besar Mahäbhārata. Teknik analisis data menggunakan teknik reduksi data, tahap penyajian data (display) dan tahap penarikan kesimpulan (verifikasi). Hasil dari kajian penelitian ini akan disampaikan dalam bentuk deskriptif atau narasi mendalam yang memenuhi ciri-ciri keilmuan bersifat ilmiah. Bahasa yang digunakan adalah bahasa Indonesia dengan gaya bahasa formal, nalar, obyektif, jelas, tepat dan argumentatif.

\section{PEMBAHASAN}

\section{Kewajiban Raja Adalah Ilmu Tertinggi}

Yudhișthira sebagai penerus Wangsa Kuru yang akan melanjutkan memimpin kerajaan Hastinapura mengawali pertanyaan kepada Bhisma perihal kewajiban dari pada seorang raja. Yudhișthira bertanya "telah dikatakan oleh orang bijaksana bahwa kewajiban raja merupakan ilmu tertinggi, tolong beritahu saya tentang kewajiban sorang raja". Mendengar hal tersebut Bhisma sangat senang dan berkata "Anakku, saya sangat ingin memberimu semua yang kamu ingin ketahui". (Mayuni, dkk. 2013: 50).

Pertama, raja adalah memuja para Dewa dan Brahmana. Dalam keyakinan Hindu Dewa pada dasarnya merupakan manifestasi dari Ida Sang Hyang Widhi Wasa yang 
secara otomatis merupakan bagian dari alam semesta yang patut dihormati. Seorang raja harus pula meyakini bahwa bahwa Dewa sebagai manifestasi Tuhan merupakan bagian dari Tuhan itu sendiri sehingga seorang raja mampu menumbuhkan rasa sujud bhakti pada Tuhan. Tidaklah mungkin seorang manusia akan melakukan sujud bhakti pada Tuhan apabila tidak meyakini keberadaan dari Tuhan itu sendiri.

Keyakinan akan keberadaan Tuhan yang meresapi segala yang ada termasuk didalamnya adalah Dewa sebagai manifestasi Tuhan menjadi bagian utama dalam upaya memahami hakikat dari Tuhan itu sendiri. Oleh karena itu terlebih dahulu perlu adanya śraddhā atau keyakinan/kepercayaan. Dalam Yajur Veda XIX.30 disebutkan sebagai berikut:

Vratena dỉkșāmāpnoti dìkșayā"pnoti

dakșinām, dakṣinā śraddhāmāpnoti

śraddhayā satyamāpyate

Terjemahannya:

(YajurVeda XIX.30)

Dia mencapai kepercayaan doa: dengan kepercayaan datang pengetahuan kebenaran. (Dewanto, 2005:379).

Berdasarkan kutipan Yajur Veda tersebut menguraikan bahwa setiap manusia harus memiliki sebuah kepercayaan atau keyakinan karena hal tersebut juga merupakan sumber dari pengetahuan, termasuk didalamnya meyakini keberadaan Tuhan yang menjadi asal dari segala yang ada. Hal tersebut tentu akan mengarahkan setiap manusia semakin menghormati apapun yang ada dalam alam semesta termasuk para Dewa sebagai manifestasi Tuhan yang memiliki derajat lebih tinggi dari manusia. Artinya setiap manusia khususnya seorang raja harus melakukan penghormatan pada para Dewa untuk mendapatkan anugerah dalam menjalankan kehidupan.

Selain para Dewa, yang harus dihormati oleh seorang raja adalah Brahmana. Secara umum penghormatan kepada Brahmana patut dilakukan oleh setiap manusia tanpa terkecuali bagi seorang raja. Brahmana merupakan golongan masyarakat yang memiliki kedudukan dan tugas pekerjaannya adalah mengajarkan ilmu pengetahuan suci (ilmu agama) dengan tujuan agar masyarakat hidup damai dan sejahtera. Kesucian Brahama bahkan dinyatakan bahwa golongan tersebut terlahir dari kepala atau mulut Ida Sang Hyang Widhi (Suhardana, 2013: 656-657) yang artinya seorang Brahmana Memiliki peranan penting dalam memberikan pemikiran-pemikiran dalam setiap keputusan yang dilakukan oleh seorang raja agar tidak menyimpang dari ajaran dharma.

Kesucian yang dimiliki seorang Brahmana harus dihormati oleh seorang raja karena segala sumber ajaran pengetahuan suci bersumber padanya. Pengetahuan 
adalah hal penting yang patut dimiliki oleh setiap manusia apalagi seorang pemimpin, pengetahuan yang akan mengarahkan setiap manusia untuk lepas dari kegelapan kebodohan yang menyelimuti segala indrya. Dengan demikian, harus dipahami bahwa kekuatan dari Brahama adalah pengetahaun itu sendiri. Hal ini juga tertuang dalam pustaka suci Cāṇakya Nìti Śāstra II.16 sebagai berikut:

balam vidyā viprānāàm rājām sainyam balàm tathā

balam vittà̇ ca vaiśyānāì śudrānāì ca kanișthikā

Terjemahan:

Kekuatan dari Brāhmana adalah ilmu pengetahaun suci, kekuatan dari raja adalah bala tentara yang tangguh, kekuata dari vaiśya adalah kekayaan dan kekuatan dari śüdra adalah sifat melayani (Darmayasa, 2014: 17).

Kutipan Cānakya Nìti Śāstra di atas sangat jelas menyebutkan bagaiaman golongan Brahmana memiliki peranan penting dalam memberikan pengetahuan suci kepada seorang raja dalam upaya mengarhakan pemikiran menuju arah yang benar, sehingga apapun keputusan raja akan selalu mempertimbangakan nilai-nilai suci yang tertuang dalam pustaka-pustaka suci.

Pentingnya pengetahuan suci juga terdapat dalam asas kepemimpinan Hindu yang terdapat dalam buku "Tata Negara Majapahit Parwa III" dijelasakan bahwa terdapat empat utama yang patut diketahui dan dilaksanakan oleh seorang pemimpin, yang salah satunya adalah Jana Wisesa Sudha artinya seorang pemimpin harus menguasai ilmu pengetahuan suci, baik yang bersumber dari manusia, maupun dari Tuhan atau kitab suci Veda. Pengetahuan suci ini perlu dipelajari untuk digunakan dengan tujuan yang suci pula (Suhardana, 2008: 70-71).

\section{Kebenaran Sumber Kepercayaan Rakyat}

Hal berikutnya yang disampaikan oleh Bhisma adalah "kewajiban seorang raja yang sama penting berikutnya adalah kebenaran. Kalau kamu ingin menumbuhkan kepercayaan di dalam pikiran rakyatmu, kamu harus selalu mengatakan kebenaran" (Mayuni, dkk, 2013:51). Seorang raja harus membangun kepercayaan dari rakyat yang dipimpinnya dalam upaya memberikan rasa aman dan nyaman terhadap rakyat karena tugas utama dari seorang raja adalah memberikan kebahagian dan perlindungan.

Kejujuran dan keterbukaan seorang pemimpin menjadi sumber utama kepercayaan rakyat, seorang pemimpin tidak boleh berbohong pada rakyat yang pimpinnya. Memperoleh kepercayaan rakyat menjadi salah-satu upaya untuk 
mendapatkan rasa simpatik sehingga apapun yang dilakukan kedepan akan mendapat kemudahan.

Setiap manusia apalagi seorang pemimpin harus memiliki kemampuan untuk menarik simpatik dari rakyatnya. Dalam ajaran Hindu hal ini selaras dengan konsep Catur Paramitha yaitu empat sifat dan sikap yang utama, dalam hal ini dikaitkan dengan konsep kepemimpinan empat sifat dan sikap inilah yang harus dikuasi oleh seorang pemimpin. Keempat sifat dan sikap tersebut adalah maitri, Karuna, Upeksa, dan Mudhita. Dari keempat bagian dari CaturParamitha tersebut bagian keemapat (Mudhita) menjadi bagian yang cukup penting dimana mudhita diartikan sebagai usaha untuk mendapatkan simpati orang lain. Hal ini dilakukan seorang raja dengan maksud tidak lain adalah dalam upaya menyatukan diri bersama rakyat yang dipimpinnya.

Untuk dapat mendapatkan kepercayaan dari rakyat maka konsep dasar agama Hindu yaitu Tri Kaya Parisudha juga menjadi jalan yang patut dilakukan. Dalam hal ini salah satu bagian dari konsep tersebut adalah wacika parisudah atau gerak lidah/perkataan. Salah-satu bagian yang tidak patut dilakukan dalam pengendalian perkataan adalah Tan Mitya atau tidak berbohong (Ida Pedanda Kemenuh, 2012: 4). Hal ini juga dapat digunakan sebagai pegangan dari seorang raja dalam upaya memberikan rasa aman dan nyaman pada rakyatnya.

\section{Keadilan Menjadi Pegangan Seorang Raja}

Ajaran dharma seorang raja berikutnya yang disampaikan oleh Bhisma pada Yudhișthira adalah "keadilan harus menjadi sifat kedua seorang raja". Memberikan keadilan menjadi kewajiban utama seorang raja, keadilan menjadi tanggung jawab bagi seorang raja selaku pemimpin dalam lingkungan rakyat tersebut. Keberanian dan ketegasan seorang raja menjadi peran utama dalam hal memberikan keadilan pada rakyat yang dipimpinnya.

Asas kepemimpinan Hindu khusunya yang terdapat dalam Kakawin Ramayana juga menjelaskan bahwa seorang seorang pemimpin harus selalu memegang teguh keadilan bagaiakan Dewa Yama yang tanpa pilih kasih menegakan keadilan dan kebenaran. seorang raja harus tegas dalam memberikan hukuman kepada yang bersalah dan melindungi orang-orang yang tidak bersalah.

Mengacu pada beberapa teks teologi Hindu yang didalamnya mengandung ajaran-ajaran kepemimpinan, terdapat penjelasan mengenai kewajiban seorang raja atau 
pemimpin dalam menegakkan keadilan. Hal ini tertuang dalam pustaka suci Mānava Dharmaśastra VII.20 yang menguraikan sebagai berikut:

Yadi na pranayed rājā dandam

dandyeșva tandritah

süle matsyānivā pakșyan

durbalān balavattarāh

Terjemahannya:

(Mānava Dharmaśāstra VII. 20)

Bila raja tidak tidak menghukum, dengan tidak jemu-jemunya kepada orang yang patut dihukum, (maka) yang kuat akan melalap yang lemah, seperti ikan dalam tempayan (Pudja, 2004: 291).

Berdasarkan kutipan sloka Mānava Dharmaśāstra VII. 20 sangat jelas bahwa raja hendaknya mampu memberikan keadilan kepada rakyat yang pimpinnya serta mampu menegakan keadilan dengan cara selalu mengacu pada dharma dan menjauhi adharma. Pemimpin yag mampu menegakan keadilan akan memberikan rasa aman bagi seluruh rakyat dan menjadi contoh yang baik bagi masyarakat.

Selain pustaka suci Mānava Dharmaśāstra, ajaran politik dan kepemimpinan Hindu juga tertuang dalam Artha Śāstra yang disusun oleh Caṇakya. Ajaran Caṇakya berfokus pada tataran bahwa negara adalah institusi tertinggi yang wajib dan harus dijaga keberlangsungannya. Dalam hal ini raja atau pemimpin memiliki kuasa dan tanggung jawab dalam menjalankan roda negara (Avalokitesvari, 2019: 22-23).

Berdasarkan pandangan tersebut, seorang raja memiliki tanggung jawab besar untuk menjaga kedaulatan suatu negara atau daerah yang dipimpinnya. Agar nantinya dapat menciptakan kedaulatan dan kedamaian serta kesejahteraan rakyat tentunya seorang pemimpin harus mengutamakan kebahagiaan rakyat yang dipimpinnya. Kebahagian rakyat akan menjadi kebahagiaan pula bagi dirinya, hal ini sesua dengan ajaran Artha Śāstra 1.19.34 sebagai berikut:

Prajā sukhe sukham räjñah

prajānāim ca hita hitam

nātma-priyam hitam rājñah

prajānām tu priyaṁ hitam

(Artha Śāstra Buku I, bab 19,bag.16, ayat 34)

Terjemahan:

Kebahagiaan rakyat adalah letak kebahagiaan raja, dan apa yang bermanfaat bagi rakyatnya juga bermanfaat bagi dirinya sendiri. Apa yang berharga bagi dirinya sendiri belum tentu bagi Negara, tetapi apa yang berharga bagi rakyatnya adalah bermanfaat bagi dirinya (Astana, 2005:63).

Kutipan yang terdapat dalam Artha Śāstra kembali memperkuat pemahaman umat Hindu bahwa seorang raja wajib memberikan kebahagian kepada rakyat yang 
pimpinnya, dan upaya memberikan kebahagian pada rakyat salah-satunya adalah berlaku adil dan selalu memegang teguh kebenaran.

\section{Raja Harus Mampu Menaklukan Diri Sendiri}

Pernyaan lain yang disampaikan oleh Yudhișthira kepada Bhisma adalah "kewajiban lain apa yang harus dilakukan oleh seorang raja?" Bhisma menjawab "pertama seorang raja harus tau bagaimana menaklukan dirinya sendiri, apabila sudah mencapai ini maka kemudian dia harus mencoba menaklukan musuhnya. Penaklukan lima indria dianggap kemenangan yang terbesar. Hanya raja seperti itulah yang mampu menaklukan musuhnya" (Mayuni, dkk, 2013:56).

Pengendalian indria yang dimiliki oleh manusia menjadi hal yang hingga saat ini menjadi hal yang sangat sulit dilakukan. Hal ini disebabkan pengaruh maya yang menyebabkan manusia dipenuhi dengan keinginan dalam upaya memuaskan indriaindria yang dimiliki. Pengendalian diri terdengar sangat mudah dilakukan, namun realitanya hal inilah yang selalu menghambat umat manusia khususnya umat Hindu untuk mencapai tujuan tertinggi yang disebut dengan moksa.

Sumber dari segala keinginan yang muncul dalam diri manusia berasal pikiran sebagai raja dari segala indria. Pikiran menjadi titik awal munculnya setiap keinginan manusia, sehingga pikiran menjadi hal penting untuk dapat dikendalikan dalam upaya mengendalikan seluruh indria lainnya. Pengendalian pikiran akan mengarahkan penarikan indria-indria lainnya sehingga mampu mencapai kesadaran tertinggi dan memahami secara utuh bahwa tujuan utama dalam kehidupan adalah mendapatkan kepuasan dari Tuhan dan bukan hanya mendapatkan kepuasan duniawi semata. Secara teologis hal tersebut teruang dalam pustaka suci Bhagavad Gita II. 58-59 sebagai berikut:

Yadà samiharate cāyam

Kūrmo'ingāniva sarvaśạ

indriyāniñ driyārthebhyas

tasya prajñā pratișthitāa

Terjemahan:

(Bhagavadgita II.58)

Sebagaimana kura-kura menarik anggota-anggota badannya dari seluruh arah, seperti itu pula ketika orang menarik seluruh indrianya dari obyek-obyek indria, maka saat itu kesadarannya menjadi mantap sempurna (Darmayasa, 2014: 258).

vișayā vinivartante

nirāhārasya dehinah

rasa-varjaì raso 'py asya

param drsșū nivartate

(Bhagavadgita II.59) 
Terjemahan:

Mereka yang sudah menjauhkan indria-indrianya dari obyek-obyek indria barangkali obyek indria-indria terjauhkan tetapi rasa kepuasan indria masih tetap ada. Akan tetapi, dengan mengalami rasa kepuasan yang maha tinggi di dalam Tuhan Yang Maha Esa, maka rasa kepuasan duniawi menjadi tidak ada (Darmayasa, 2014:258).

Berdasarkan kedua kutipan Bhagavadgita yang juga merupakan bagian tak terpisahkan dalah kisah Mahābhārata di atas, dapat ditarik benang merah bahwa pengendalian indria-indria manusia menjadi hal utama dalam kehidupan. Hal ini tentu juga berlaku pada seorang raja sebagai pemegang pemerintahan. Selaku pemegang jabatan tertinggi seorang raja harus lebih mampu mengandalikan diri dibandingkan rakyat yang dipimpinnya, hal ini tentu tidak mudah dilakukan sehingga seorang yang berani mengambil tugas sebagai seorang raja adalah bukan orang biasa karena diyakini memiliki kemampuan lebih dalam berbagai hal tanpa terkecuali mempunyai kelebihan dalam mengendalikan indria-indrianya.

Apa yang disampaikan oleh Bhisma mengenai pengendailan diri sesungguhnya telah diimplementasikan oleh Yudhișțira dalam kehidupannya. Salah-satu bentuk pengendalian diri dari Yudhișțira dilakukan dalam masa pengasingannya di hutan. Hal ini tertuang dalam percakapan antara Drupadi dan Yudhiștira pada bagian wana parwa yang didalamnya menguraikan awal perjalanan pandawa meninggalkan ibukota Hastinapura menuju pengasihan ke hutan selama dua belas tahun.

Saat menjalankan masa pengasingan yang tentunya menimbulkan kemarahan dari Drupadi yang merasa tidak terima melihat Pandawa dan dirinya hidup dalam segala keterbatasan di Hutan selama bertahun-tahun. Kemarahan Drupadi tidak mampu terbendung dan berkata kepada Yudhișțira untuk membunuh pidah Korawa dengan kekuatan Bima yang tak terkalahkan. Dengan mudahnya Yudhiștira menjawab "kemarahan adalah pembunuh orang dan penghalang sesuatu hasil kemakmurannya. Juga kemarahan adalah pangkal dari semua kemalangan. Kemarahan menjadi sebab kehancuran. Oleh karena itu orang bijaksana meneliti kemarahannya. Kelahiran setiap makhluk adalah untuk berdamai. Ampunan adalah kebajikan, ampunan adalah Brahmā, ampunan adalah Tuhan, ampunan adalah kebenaran, ampunan adalah suci (Sangka, 1998: 9-10).

Inilah bukti nyata dari apa yang disampaikan oleh Bhisma kepada Yudhiștira dalam upaya mengendalikan diri. Hal lain yang disampaikan Bhisma kepada Yudhiștira dalam medan perang sebagai pegangan atau dharma seorang raja adalah selalu waspada, 
tidak mudah percaya pada siapapun, tidak boleh bersikap terlalu lembut dan terlalu keras, bertutur kata yang manis, tidak memendam rasa dengki, dan tau kapan harus berlindung dan siap berdamai dengan musuh yang lebih kuat.

\section{PENUTUP}

Dharma seorang raja yang disampaikan oleh Bhisma kepada Yudhiștira merupakan sebuah ajaran kepemimpinan yang didalamnya terkadung nilai-nilai ketuhanan atau biasa disebut dengan istilah teologi. Hal ini terlihat dari penyampain Bhisma yang menjelaskan kepada Yudhiștira tentang apa yang patut dan tidak patut dilaksanakan oleh seorang raja. Dalam percakapannya Bhisma menyampaikan beberapa hal yang menjadi dharma bagi seorang raja sebagai ilmu tertingi yang harus dimiliki oleh seorang raja atau pemimpin, diantaranya yaitu selalu memegang teguh kebenaran, keadilan, mampu menaklukan diri sendiri, selalu waspada, tidak mudah percaya pada siapapun, tidak boleh bersikap terlalu lembut dan terlalu keras, bertutur kata yang manis, tidak memendam rasa dengki, dan tau kapan harus berlindung dan siap berdamai dengan musuh yang lebih kuat.

\section{DAFTAR PUSTAKA}

Astana, Made. 2005. Artha Sastra (Masalah Politik, Ekonomi, Hukum, Budaya dsb). Surabaya: Paramita

Avalokitesvari, Ni Nyoman Ayu Niki. 2010. Cānakya Arthaśāstra Warisan Politik Kenegaraan Hindu dala Politik Hindu, Sejarah, Moral dan Proyeksinya. Program Pascasarjana IHDN Denpasar: IHDN Press.

Darmayasa, I Made. 2014. Cāṇakya Nīti Śāstra. Surabaya: Paramita

Dewanto. 2005. Yajur Veda Saminitā (Terjemahan). Surabaya: Paramita.

Ida Pedanda Kemenuh, 2012. Trikaya Parisuda dan Catur Prawerti. Denpasar. PT Mabhakti.

Ketut Sangka, I Gusti Ngurah. 1998. Wana Parwa terjemahan dari The Mahabharata of Krishna Dwaipayana Vyasa. Surabaya: Paramita.

Mayuni, A.A Inten, dkk. 2013. Kisah Setalah Bharatayudha. Denpasar. CV. Setia Bakti

Pudja, G. \& Sudharta, Tjokorda Rai. 2004. Mānava Dharmaśāstra (Manu Dharmaśāstra). Surabaya: Paramita

Suhardana, K.M, 2008. Niti Sastra Ilmu Kepemimpinan atau Management Berdasarkan Agama Hindu. Surabaya: Paramita

Suhardana, K.M. 2013. Ensiklopedia Hindu Jilid I. Surabaya: Paramita

Suhardana, K.M. 2013. Ensiklopedia Hindu Jilid II. Surabaya: Paramita.

Sujana, I Made, dkk. Bahan Ajar Tatwa. Kementerian Agama RI Direktur Jenderal Bimbingan Masyarakat Hindu. 